\section{Issues in \\ Informing Science + \\ Information Technology}

An Official Publication

of the Informing Science Institute

InformingScience.org

Volume 16, 2019

IISIT.org

\title{
TRANSITION TO FIRST YEAR UNIVERSITY STUDY: A QUALITATIVE DESCRIPTIVE STUDY ON THE PSYCHOSOCIAL AND EMOTIONAL IMPACTS OF A SCIENCE WORKSHOP
}

Jyothi Thalluri*

Joy Penman

* Corresponding author
University of South Australia, Adelaide, Australia

Monash Univeristy, Melbourne, Australia jyothi.thalluri@unisa.edu.au

joy.penman@monash.edu

\section{ABSTRACT}

Aim/Purpose

The purpose of this article is to discuss the psychosocial and emotional outcomes of an introductory health science workshop designed to support and assist incoming health science students before starting their university study.

Background

For the past two decades, a South Australian university offered an on-campus face to face workshop titled 'Preparation for Health Sciences' to incoming firstyear students from eleven allied health programs such as Nursing, Physiotherapy and Medical Imaging. While many were locals, a good number came from regional and rural areas, and many were international students also. They consisted of both on-campus and off-campus students.

The workshop was created as a new learning environment that was available for students of diverse age groups, educational and cultural backgrounds to prepare them to study sciences. The content of the four-day workshop was developed in consultation with the program directors of the allied health programs. The objectives were to: introduce the assumed foundational science knowledge to undertake health sciences degree; gain confidence in approaching science subjects; experience lectures and laboratory activities; and become familiar with the University campus and its facilities. The workshop was delivered a week before the orientation week, before first-year formal teaching weeks. A typical workshop covered enhancing study skills, medical and anatomical terminology, body systems, basic chemistry and physics, laboratory activities and assessment of learning.

Accepting Editor: Eli Cohen | Received: November 24, 2018 | Revised: January 13, January 15, April 5, 2019 | Accepted: April 7

Cite as: Thalluri, J., \& Penman, J. (2019). Transition to first year university study: A qualitative descriptive study on the psychosocial and emotional impacts of a science workshop. Issues in Informing Science and Information Technology, 16, 197-210. https://doi.org/10.28945/4297

(CC BY-NC 4.0) This article is licensed to you under a Creative Commons Attribution-NonCommercial 4.0 International License. When you copy and redistribute this paper in full or in part, you need to provide proper attribution to it to ensure that others can later locate this work (and to ensure that others do not accuse you of plagiarism). You may (and we encourage you to) adapt, remix, transform, and build upon the material for any non-commercial purposes. This license does not permit you to use this material for commercial purposes. 
Methodology In order to determine the outcomes of the workshop, a survey was used requiring participants to agree or disagree about statements concerning the preparatory course and answer open-ended questions relating to the most important information learned and the best aspects of the workshop. Several students piloted this questionnaire before use in order to ascertain the clarity of instructions, terms and statements used. The result of the 2015-2018 pre- and postevaluations showed that the workshop raised the confidence and enthusiasm in commencing university of the majority of the participants. The majority considered the workshop to be useful overall. The findings of the survey were drawn upon to examine the psychosocial and emotional impacts of the workshop on participants. Using secondary qualitative analysis, the researchers identified the themes relating to the psychosocial and emotional issues conveyed by the participants.

Contribution The contributions of the article are in the areas of improving students' confidence to complete their university degrees and increasing the likelihood of academic success.

Findings $\quad$ Of the 285 students who participated in the workshops from 2015 to 2018,166 completed the survey conducted at the conclusion of the initiative, representing a $58 \%$ response rate. The workshops achieved the objectives outlined at the outset. While there were many findings reported (Thalluri, 2016), the results highlighted in this paper relate to the psychosocial and emotional impacts of the workshop on students. Three themes emerged, and these were Increased preparedness and confidence; Networking and friendships that enhanced support, and Reduced anxiety to study sciences. Some drawbacks were also reported including the cost, time and travel involved.

Recommendations for Practitioners

Students found the introductory workshop to be psychosocially and emotionally beneficial. It is recommended that the same approach be applied for teaching other challenging fields such as mathematics and physics within the university and in other contexts and institutions.

Recommendations Improving and extending the workshop to provide greater accessibility and aufor Researchers tonomy is recommended. A longitudinal study to follow up the durability of the workshop is also proposed.

Impact on Society The impacts to the broader community include: higher academic success for students; improved mental health due to social networking and friendship groups and reduced anxiety and fear; reduced dropout rate in their first year; greater potential to complete educational degrees; reduced wastage in human and financial resources; and increased human capital.

Future Research Addressing the limitations of cost, time and travel involved, and following-up with the participants' academic and workplace performance are future directions for research.

Keywords transition to university, first year, psychosocial, anxious

\section{INTRODUCTION}

For the past two decades, a South Australian university has been offering an on-campus face to face workshop titled 'Preparation for Health Sciences' to incoming first-year students from eleven allied health programs such as Nursing, Physiotherapy and Medical Imaging. The study of sciences has always been a perennial challenge for beginning university students and so this initiative was conceptualized to address this 'phobia' of sciences. 
The participating students were heterogeneous, coming from different fields of interest and educational backgrounds. While many were locals, there were some from regional and rural areas. There were domestic as well as international students, studying either on-campus or off-campus. About $40 \%$ of students who enrolled in this workshop were first member in the family to go to university.

The workshop described here aimed to prepare allied health students to study sciences. The content of the four-day workshop, which was optional and fee-paying, was developed in consultation with the program directors of the allied health programs. The workshop was delivered a week before the orientation week, which is prior to the commencement of the first year formal teaching weeks. During this orientation period, time is spent to prepare for University, make connections and meet new people. The workshop covered study skills, medical and anatomical terminology, basic biological concepts of body systems, basic chemistry and physics, laboratory activities, and assessment of learning. The aims were to expand on the assumed foundational science knowledge, increase students' confidence in approaching science subjects, and introduce students to lectures and laboratories, the University campus and its facilities.

The outcomes of the workshop have been evaluated and reported (Thalluri, 2016). In the main, the workshop assisted students' university transition into health science programs. It was reported that it improved the participants' confidence and enthusiasm in commencing university by $60 \%$ and was effective in preparing students for sciences according to $97 \%$ of the participants. Specifically, the illumination of biological principles was found beneficial by $87 \%$ of students.

However, the full impact of this preparatory course has not yet been fully ascertained. The psychosocial and emotional outcomes have not been given sufficient attention in previous publications. The terms psychosocial and emotional refer to the close link between the individual's thought and behaviour and the collective aspects of social and emotional factors. These factors are important because they impact on transition to first year university study. Thus, this study was undertaken to clarify the psychosocial and emotional impacts of the workshop on participants. In clarifying these outcomes, further improvement may be made to inform future workshop offerings.

\section{BACKGROUND}

Gaining a tertiary qualification is a significant achievement particularly true for students who are first in the family to pursue tertiary education. A bachelor's degree provides graduates discipline-specific knowledge and skills, broader social networks, and greater employment options and income (Allen, 2007; Strawiński, 2011). However, participation in higher education is not easy. A number of interacting factors influence success in higher education. Demographic characteristics, such as sex, education level, income level, family background, and employment are some of these factors (Andres \& Adamuti-Trache, 2008; Maani, 2006; Maaz \& Watermann, 2007; Wilks \& Wilson, 2012). Pursuing tertiary education in a particular university is determined by various considerations, namely university rankings, affordability, availability of scholarships, as well as safety concerns (Gong \& Huybers, 2015).

Less attention has been directed to the expectations of students when they enter an institution for the first time. Students' expectations may not necessarily align with the realities of common university practices (Crisp et al., 2009). The need to understand the expectations of students commencing university is becoming important (Scutter, Palmer, Luzeckyj, Burke da Silva, \& Brinkworth, 2011). Moreover, Becker (2017) following her study utilizing a mixed methods approach, conclude that curricular and instructional intervention/s may be required for students' readiness for university. During university study, students experience academic and non-academic challenges (Hamaideh, 2011). These challenges have caused various levels of stress amongst undergraduate students (Cooke, Barkham, Audin, Bradley, \& Davy, 2004; Eisenberg, Gollust, Golberstein, \& Hefner, 2007; Stallman, 2010). The sources of stress emanate from academic, socio-economic and environmental problems. It is crucial to address possible stressors to ensure students continue their studies. Consequently, various institutional responses have been devised to prevent students from dropping out (Penman, 
2005). University-based initiatives such as the organisation of the orientation week, introduction to library services and information technology, student support officer involment (Konovalov, Sealey, \& Munns, 2017), peer-mentoring program, learning advisory services, and early identification and support of students at risk, are some examples to ensure academic success, positive experiences and satisfaction in health science programs, and student retention.

The first year at university is crucial and assistance during the transition is paramount (Kift, 2014). Wilson and Lizzio (2008) reported that the success or failure in the first year of university is premised on some factors, foremost of which was the provision of a range of support systems for the students. A third of students tended to drift anxiously, and expected to meet the challenges on their own. This 'drifting' is severe for those students who have limited resources to support them. High rates of depression and stress were also reported amongst first-year university students in Hong Kong (Wong, Cheung, Chan, Ma \& Tang, 2006). This outcome prompted the researchers to emphasise the need for preventative interventions, including support services for beginning students. It is clear that universities must actively assist in the successful transition of first-year students.

As of late, the social transition of university students has been the focus of investigations on tertiary students. In a study of the first-year experience amongst Australian tertiary students, Hillman (2005) concluded that a significant number of those surveyed reported that they had not made close friends, leading them to disengage with the university. Based on another study from an Australian multicampus university, Kantanis (2000) reported that the students' social transition must be facilitated and this must be positive in order to ensure university success. Those unable to 'network' or transition socially have difficulty in meeting their first-year challenges. Hence, the importance of social transition as a fundamental component of the teaching program was underscored. Friedlander, Reid, Shupak, and Cribbie (2007) corroborated these findings by linking social support from friends with self-esteem and decreased stress. Pittman and Richmond (2008) highlighted how essential belonging and positive friendships are on the transition to college.

The 'Preparation for Health Sciences' workshop allowed this social transition to happen also. In this four-day-long workshop, students were familiarised to interactive lectures, activities teaching basic scientific concepts and assumed knowledge, and medical/anatomical/scientific terminology specific for certain disciplines. Students experienced laboratory sessions, examining human cells, tissues and organs in the pathology museum and anatomy laboratory. During the workshop, they were divided into groups according to their disciplines. This grouping allowed them to start working together, as well as socialise and develop networks with other students from the same or different programs. An informal self-assessment test was administered at the conclusion of the workshop to test the learning that transpired. The test was marked and returned to the students with feedback.

Wilson (2012) contend that students are more likely to succeed if they develop social network early at university. A smooth social transition is why strategies are put in place to maximise student-student and student-staff engagement. During the workshop, each student wore name tags (with their enrolled programs), so that they could identify other students within the same program or other programs. Lunch was provided daily at the foyer of the teaching area, and during this time, students met with the other students and encouraged to form early study and social groups. Also, much emphasis was given to networking with academics. Teaching staff, course coordinators, program directors, student engagement services staff were all present during lunch each day for informal conversations, and question and answer sessions. During the workshop also, learning advisers gave short presentations about the services and support systems they provided to students.

\section{METHODOLOGY}

Participants in this study were students from one of the metropolitan universities in South Australia. The outcomes of the workshop were evaluated using a survey. Quantitative and qualitative data were obtained through a survey instrument administered online. The survey required participants to choose from a five-point Likert scale statements concerning the preparatory workshop and answer 
open-ended questions relating to the most important information gained and the best aspects of the workshop. Several students piloted the survey questionnaire and commented on the clarity of instructions, statements and questions. The feedback they provided was considered in the final version of the questionnaire.

A secondary analysis was conducted; analysis referring to the re-examination of the qualitative data collected from the last three questions of the survey. The re-analysis sought to answer a new research question which was 'What psychosocial and emotional impacts did the workshop have on the participants?' This aspect of the data collected has not been examined, and so the researchers re-analysed the data to develop an original topic (Payne \& Payne, 2004). Secondary analysis allows the pursuit of a different research focus in comparison to the original research (Heaton, 1998). It is done to maximise the use of the data, generate new knowledge and reduce the cost of qualitative work. Several methodological considerations are necessary, including forming critical insights based on intersubjective understanding, and determining new and distinct data to allow for secondary analysis (Thorne, 1990; Heaton, 1998). This research approach had been used in various health science studies (Angst \& Deatrick, 1996; Szabo \& Strang, 1997).

\section{SAMPLE}

Participants were incoming health science students from eleven allied health programs such as Nursing, Physiotherapy and Medical Imaging who chose to undertake the workshop. Students who chose to participate include those: who have not done sciences at school; who have not been in the education system for many years; international students; students who were anxious about starting university; and students who felt they would be benefited with this extra assistance by enrolling in the short course. Geographical origin was not surveyed, but important participant descriptions were noted as follows: $68 \%$ females; $13 \%$ English as a second language; 37\% mature age students; $42 \%$ first member in the family to go to university; $30 \%$ had not been in education system for more than 5 years; and $73 \%$ have no/little science background.

\section{DATA COLLECTION}

The survey was conducted via SurveyMonkey at the conclusion of the workshop. Students were reached via email by sending them the SurveyMonkey link and inviting them to participate electronically in the anonymous survey.

It contained 19 open- and closed-ended questions. Items 1 to 12 provided Likert type statement the participants were asked to agree or disagree with relating to the outcomes of the workshop. The items surveyed the participants' agreement with statements at five levels (Strongly Agree, Agree, Neutral, Disagree and Strongly Disagree). The participants were asked about their perceptions on whether the workshop:

- increased their confidence to start university (Statement 1);

- provided an understanding of science concepts and principles to start their health science degree (Statement 2);

- helped develop study skills to cope with first-year university study (Statement 3);

- taught specific strategies of how to approach the study of science (Statement 4);

- gained a good understanding of how the human body is organised and how various bodily systems work (Statement 5);

- facilitated a good understanding of how the science of chemistry relate to the human body (Statement 6);

- provided a good understanding of medical terminology and meaning of medical terms (Statement 7); 
- boosted their feeling confident about studying Human Anatomy and Physiology (Statement 8);

- $\quad$ will help prepare for science studies (Statement 9);

- increased awareness of the resources available to help become a successful science student (Statement 10);

- $\quad$ still quite anxious about starting first year university (Statement 11); and

- have made early friendship (Statement 12).

Moreover, students' outlook about starting the first-year university were surveyed $(1=$ looking forward; $3=$ comfortable; $5=$ very anxious; $7=$ Very nervous) in Item 13 . Perceptions about how the workshop assisted the students were surveyed in Item 14 (i.e., gaining basic scientific knowledge, making early friendship, meeting staff members, getting to know the campus, and improving study skills). The students' preference of mode of delivery was determined in Item 15 (face-to-face oncampus, online delivery), and the reasons for their preference (Item 16).

This paper is based on the qualitative responses of the last three items focusing on the most important information gained from the workshop (Item 17), three best aspects of the workshop (Item 18), and areas for improving the workshop (Item 19).

\section{ETHICAL CONSIDERATIONS}

The University's Human Research Ethics Committee approved the administration of the survey at the conclusion of the workshop. Participants' anonymity was preserved as names were not required. Completing the survey was taken as consent. Access to data was limited to the researchers.

\section{METHOD OF ANALYSIS}

Braun and Clarke's (2006) approach was used to identify patterns or trends within the data. This sixstep framework involved becoming familiar with the responses to the questions, identifying the codes by transforming the raw data into a standardised form to depict recurring words and concepts, searching for themes, reviewing and examining the themes, defining them, synthesising and writing up the findings (Creswell, 2003 and 2013; Vaismoradi, Turunen, \& Bondas, 2013; Maguire \& Delahunt, 2017).

\section{RESULTS}

Of the 285 students who participated in four workshops from 2015 to 2018, 166 completed the survey conducted, representing a $58 \%$ response rate. The findings relevant to the topic of this article were drawn from this larger study. The result of the 2015-2018 evaluation showed that the workshop “improved students' confidence and enthusiasm in starting university (56\% pre- and $95 \%$ postworkshop), and 97\% considered the workshop effective overall" (Thalluri, 2016).

While there were many findings reported, the results highlighted in this paper relate to the psychosocial and emotional impacts of the workshop on students. Three themes emerged, and these were the most commonly recurring responses gathered: Increased preparedness and confidence; Networking and friendships that enhanced support; and Reduced anxiety to study sciences.

\section{THEME 1: INCREASED PREPAREDNESS AND CONFIDENCE}

The workshop helped the students psychologically and emotionally by increasing their readiness for science study. Consider these direct quotes from participants (identified by participant response number and year of participation):

The program changes most students' mind concepts on UNI life, making it go from the 'unknown' to a sense of a home-esque environment. (Student number 27, 2017) 
Familiarised me with the environment - lecture theatre - I was worried about that - being so big wondering if I would understand and become lost in the theatre but I now know that I am just as supported as I was in smaller TAFE classes breaking down the complexities of entry to uni. Great examples of the type of education we will be getting exposed to lectures. (Student number 3, 2015)

I do feel prepared now and confident and you especially but all the staff were fantastic and friendly I was concerned that being Drs I would feel extremely inadequately educated. (Student number 2, 2017)

It allowed me to feel far better prepared for my degree especially with the practical component and the way in which the lectures and tutorials were run. (Student number 1, 2018)

It gives you a great idea of what to expect and what is expected and allows you to get an idea of basic knowledge that is essential when starting the degree. (Student number 41, 2015)

Students spoke about increasing confidence to commence university study. Preparedness and confidence went hand in hand; preparedness improved confidence. The workshop helped boost confidence in succeeding in university and confidence in studying science, pursuing a degree program, and adjusting to university life. The following statements illustrate this theme:

The Preparation for Health Sciences Workshop was extremely beneficial as it provided me with the skills and knowledge about the basic components of the human body and their functions to competently and confidently enter my Midwifery course. (Student number 57, 2017)

It gave me confidence, organisational skills, and also gave me a taste of what uni life is like. (Student number 56, 2015)

I feel completing this course was a great way to enter my course more comfortably and confidently. I enjoyed every day, and I know now I made the right choice of course because I found everything interesting and engaging. (Student number 12, 2015)

The strengths of this workshop are that enables students to not only learn/ refresh things that will be useful in their studies, but it also enables students to gather an understanding of what university life is like. (Student number 13, 2016)

\section{THEME 2: NETWORKING AND FRIENDSHIPS THAT ENHANCED SUPPORT}

The remarks below depict how networks and relationships were created, according to the participants.

Through my involvement in the workshop, I was able to network and build relationships and friendships with fellow midwifery students and lecturers. (Student number 57, 2016)

At first, I did not know what university was going to be like, so attending this workshop gave me an insight into the study load and friendships that I would make next March. I would like to say thank you to all the staff members who were in the workshop, and I would not have done it without you guys. I appreciated every minute of it and made a few friends as well. (Student number 27, 2015)

Networking gives us a chance to get used to where we need to be and the campus without hundreds of people around. The strengths also included; staying on track with basic principles and not doing too in depth initially, easing us into study and university life. (Student number 64, 2015)

Another strength is that this workshop is a great way for students to find people who are in the same course as them and give them an easy way to connect and build friendships. (Student number 53, 2015)

The lecturers go out of their way to engage you and make it interesting. The printed slides were an excellent addition too. Lunch was always a pleasure, and the practicals were thoroughly enjoyable and helped break the ice with other students. (Student number 19, 2015) 
Networks and relationships not only meant linking students with co-learners but also with key people such as lecturers, course coordinators and program directors. During the workshop, students' perceptions about their relationship and connection with co-students and staff were positive, and community-building strategies were effective as could be drawn from the excerpts below.

One of the best strengths in the workshop is that they gave the students the opportunity to communicate with the teachers in a manner that made us feel comfortable and more eager to learn. Never have I gone to a school that made me feel so fulfilled by learning. I believe that another good thing in this workshop was the opportunity to talk to the program directors because they gave us a brief introduction about what to expect in the course as well as encouraging words. (Student number 39, 2015)

Was able to meet my course coordinator who helped me answer any questions I had regarding my chosen course and also was able to find out what university life will be like getting used to university style lectures - meeting staff members and making contacts with them - understanding terminology and the curriculum before starting my university degree. (Student number 19, 2016)

I want to thank the lecturers because I got the chance to talk to them one on one regarding different topics and each conversation was very meaningful and made me feel connected and accommodated. (Student number 9, 2015)

The impact of social and emotional support was summarized as follows by these two students:

I want to thank everyone involved in this workshop; you have all helped me in calming my nerves about the university and exciting me to continue with my course and succeed. (Student number 31, 2017)

Thank you very much. You have helped me have the confidence in myself and set me some groundings for my studies ahead. (Student number 40, 2016)

\section{THEME 3: REDUCED ANXIETY TO STUDY SCIENCES}

The workshop 'Preparation for Health Sciences' that has been conducted reduced anxiety and fear as articulated explicitly by these two participants:

This series of workshops has put a dent in my anxiety regarding aspects of my knowledge \& skills. (Student number 41, 2018)

The workshop was fantastic and has reduced a lot of my fears to do with starting UNI. Thanks a lot to all the staff that have helped make it happen! (Student number 3, 2015)

Anxiety and fear were reduced through several means as could be discerned from the quotations. Some of them explained that they gained the basic knowledge required, while others were reassured and encouraged to continue their studies. Notable also for some participants was the acquisition of a new perspective and direction to proceed in their study. Examine these comments volunteered by the participants:

I am very much looking forward to my first year at university. This workshop has given me confidence in commencing my studies as I now have the basic knowledge required. (Student number 6, 2016)

Overall. I thought the workshop was a fantastic way for me to transition into university life, get an understanding of the content of my course, make new friends and also get a head start and have a better foundation to start university on. (Student number 46, 2016)

They were all very welcoming and reassuring towards students with uncertainties/confidence issues in entering a degree after being out of the educational system for years. This exchange helped me, to know that they understood that not every student has come from recent educational experiences.

(Student number 11, 2016) 
I am very excited because I have had a brief experience of what Uni life will be. I found the workshop very helpful and interesting because studying about the human body has given me a new perspective and the thought about how my own body functions the same way as what I learnt from the workshop is fascinating. (Student number 4, 2018)

Gave me a sense of direction, new perspective and satisfaction (Student number 24, 2015)

Not only was anxiety quenched for some in attending the workshop. Other impacts included the resolve to do their best and develop learning further as illustrated below:

English is not my first language. After this course is done, I know what I have to do before the start of my course. Too much stuff to do by now ... however, I will do my best. Thank you very much for your help. (Student number 8, 2018)

The workshop was enjoyable and engaging, and it increased my thirst for knowledge. I want to learn even stronger. (Student number 57, 2016)

Some drawbacks were also reported including the cost, time and travel involved in order to undertake the workshop. These sentiments are depicted as follows:

The cost was a bit expensive. (Student number 51, 2017)

I know the workshop costs money, but you get more than what you paid for. (Student number 13, 2015)

I live in the country and will be studying externally. To attend the workshop, it is expensive (travel, accommodation and fees). Reduce the cost, some students might be keen, but they cannot afford. (Student number 4, 2018)

\section{DISCUSSION}

The findings highlighting the three themes that emerged clarified the psychosocial and emotional impacts of the workshop on participants. These themes will now be discussed.

Theme 1 is about increased preparedness and confidence. It was associated with concepts such as readiness and expectations. From the students' point of view, readiness meant preparedness for the demands of university. It was increased with familiarity with the campus, infrastructure including the lecture theatre, laboratories, and student and staff facilities, as well as an understanding of university teaching formats such as lectures, tutorials, practicals. In short, readiness for university was facilitated by removing the 'unknown'. Equally important was clarifying expectations. Crisp et al. (2009) and Scutter et al. (2011) stressed the importance of aligning the expectations of the students and the university, and the workshop seemed to provide realistic expectations for students. Realizing these expectations at the outset, students were able to plan how to prepare and gauge how much effort to invest to be successful learners. The workshop helped students develop a sense of fitting in before they even walked into class, and that feeling was essential for preparedness and confidence. It led to students' feeling like their skills meet academic demands, and feeling or belief that they 'can do this'. Also, this confidence could lead them to desire to remain in their programs (Fain, 2017).

Theme 2 encapsulated networking and friendships that provided students further support which the workshop successfully achieved. In this study, $42 \%$ of students enrolled in the workshop were firstgeneration students. It was found that first-generation students tended to report lower ratings of belonging, and greater levels of depression/stress (Stebleton et al., 2014). While no tests were conducted to measure these feelings, the workshop addressed belongingness and distress as the quotations revealed.

Psychosocial and emotional considerations cover building or rebuilding social structure critical for adjusting to new environments like the university. The workshop facilitated the expansion of networks and relationships that could assist in coping, normalising, surviving and thriving in the univer- 
sity (UNICEF, n.d.). Networks and relationships not only meant linking students with students, but students and lecturers, course coordinators and program directors. These are critical for successful transition (Larmar \& Ingamells, 2010; Fain, 2017). These relationships need to be positive and palpable, and community-building strategies effective.

The findings highlight the part played by social support in the successful transition to university (Wilcox, Winn \& Fyvie-Gauld, 2005). Emphasis is placed on the seamless integration into the university's sociocultural milieu as into its academic environment. After analysis of the interviews with 34 freshmen students, the same authors confirmed the relationship between 'social integration (or lack of it)' and university retention. In other words, student connectivity played a compelling role in the successful transition and retention of university students (Larmar \& Ingamells, 2010). Success at university depended upon students' feelings of connectedness, according to Lizzio (2006), and Prasad, Showler, Ryan, Schmitt, and Nye (2017).

The above studies corroborated the data collected in this research about the value of making suitable friendships that might determine decisions to remain or leave university. Such friends provided connection, encouragement, and direct psychosocial and emotional support, which could serve as real and/or potential support in stressful situations at the university. Reblin and Uchino (2008) reported the link between social and emotional support and physical health. Various pathways and mechanisms could explain the protective effects of social and emotional support on health.

Theme 3 embodied another way by which the workshop helped students psychologically and emotionally. It reduced anxiety in the study of sciences, according to the majority of participants. Anxiety and fear were reduced in various ways as previously mentioned.

Several studies in the United Kingdom suggested that that there was high level of anxiousness and emotional disturbances amongst first-year incoming students (Macaksill, 2013). In fact, a high number of first year students were referred to student advisors. In addition, students' anxiety towards sciences and the university needs to be addressed to function well at university. In investigating the correlation between stressors and study variables experiences by students, Hamaideh (2011) concluded that the common stressors were 'self-imposed'. Moreover, the management of stress and time, learning assertiveness skills, and attending counselling sessions have been shown to be effective in reducing these 'self-imposed' stressors amongst students. The participants in this study experienced this anxiety also.

A recent report by Unihealth (University Business, 2017) on British university students revealed that $82 \%$ of students admit experiencing stress and anxiety, and almost half ( $45 \%)$ suffer from depression. More students were leaving the university due to mental health-related issues. The economic cost of dropping out for each student is approximately $£ 33,000$. The significance of providing appropriate support services to help students remain at university was emphasized.

Personalized learning has relevance when attempting to explain how the workshop accomplished the positive impacts. It involved learning experiences and academic support strategies that addressed specific learning needs (Johnson et al., 2016). The goal in personalizing learning was to 'empower' students to take charge and ownership of the learning, to give them the responsibility, stimulation and inspiration, and strategies to engage with the content (Johnson et al., 2016, p.28). Further, facilitating students to grasp the insight about areas requiring focus was essential, especially when beginning to study sciences at the university. In personalizing the learning, students' anxiety was reduced, resources were identified and carefully considered, and their confidence boosted.

Some areas to improve on were likewise reported. Introducing the online version of the workshop may suit those students who found the cost, time and travel prohibitive in participating in the workshop. The online version of the workshop will include virtual classroom and group discussion, discussion board to avoid isolation from staff and peers, to provide opportunities to make friendship groups and get to know the staff involved in the program enrolled. 


\section{CONCLUSION}

There has been an increasing focus on the psychosocial and emotional support provided to students because of concerns about belonging, fitting-in the university, anxiety and even fear, and student retention. Determining cogent strategies for assisting beginning university students is imperative. There is an emerging body of literature that highlights the usefulness and efficacy of well-being support services and early learning experiences that might address some of the concerns of first-year undergraduate students. Support during or prior to the first year is crucial to reduce the drop-out rate.

Over the past decades, the workshop titled 'Preparation for Health Sciences' has been offered to first-year students from various allied health programs with the aim of preparing them to study sciences. The workshop was a strategy to create and develop a new learning environment that was available and accessible to students to prepare them to study sciences, strengthen them with the required knowledge and skills, and facilitate a greater understanding of biological principles.

In implementing the workshop, a serendipitous outcome was uncovered pertaining to the psychosocial and emotional impacts of the workshop on the participants. Following a secondary analysis of the evaluation data, these translational outcomes for the students were clarified. The three themes that emerged from data analysis, namely, Increased preparedness and confidence, Networking and friendships that enhanced support, and Reduced anxiety to study sciences, answered the research question 'What psychosocial and emotional impacts did the workshop have on the participants?' These outcomes could be linked with personalizing learning.

Myriads of extra ongoing support prior and during first year of university study would reduce anxiety and bring calmness and readiness to take a big step. Smooth student transition is an important factor. University readiness, connectedness, networking, friendships, and reducing anxiety helped changed students' perceptions about the university. These findings demonstrate that the workshop could assist students' transition and adaptation into their programs and the university in general. Future directions include addressing the drawbacks reported, asking students what support they expect from the university for their mental health and wellness, improving the program further by providing greater accessibility and autonomy to students, and conducting a longitudinal study to follow up the durability of the teaching and learning that happened during the workshop.

\section{REFERENCES}

Allen, H. (2007). Why is higher education important? Crosswalk.com. Retrieved from http://www.crosswalk.com/family/homeschool/why-is-higher-education-important-1367463.html

Andres, L., \& Adamuti-Trache, M. (2008). Life-course transitions, social class, and gender: A 15-year perspective of the lives of Canadian young adults. Journal of Youth Studies, 11(2), 115-145. https://doi.org/10.1080/13676260701800753

Angst, D. B., \& Deatrick, J. A. (1996). Involvement in health care decisions: Parents and children with chronic illness. Journal of Family Nursing, 2(2), 174-95. https://doi.org/10.1177/107484079600200205

Becker, H. C. (2017). High school to college transition: A mixed methods approach to improve student understanding of college readiness. Doctoral dissertation. Texas A\&M University. Retrieved from https://oaktrust.library.tamu.edu/bitstream/handle/1969.1/169596/becker-recordofstudy-2017.pdf

Braun, V., \& Clarke, V. (2006). Using thematic analysis in psychology. Qualitative Research in Psychology, 3(2), 77 101. https://doi.org/10.1191/1478088706qp063oa

Cooke, R., Barkham, M., Audin, K., Bradley, M., \& Davy, J. (2004). Student debt and its relation to student mental health. Journal of Further and Higher Education, 28(1), 53-66. https://doi.org/10.1080/0309877032000161814

Creswell, J. W. (2003). Research design: Qualitative, quantitative and mixed methods approaches (2nd ed.). Thousand Oaks CA: Sage Publications. 
Creswell, J. W. (2013). Qualitative inquiry \& research design: Choosing among five approaches (3rd ed.). Thousand Oaks, CA: Sage Publications.

Crisp, G., Palmer, E., Turnbull, D., Nettelbeck, T., Ward, L., LeCouteur, A., Sarris, A., Strelan, P., \& Schneider, L. (2009). First year student expectations: Results from a university-wide student survey. Journal of University Teaching and Learning Practice, 6(1), 11-26. Retrieved from https:/ / files.eric.ed.gov/ fulltext/EJ867293.pdf

Eisenberg, D., Gollust, S. E., Golberstein, E., \& Hefner, J. L. (2007). Prevalence and correlates of depression, anxiety, and suicidality among university students. American Journal of Orthopsychiatry, 77(4), 534-542. https://doi.org/10.1037/0002-9432.77.4.534

Fain, P. (2017). Study on first-year orientation and retention. Inside Higher Ed. Retrieved from https://www.insidehighered.com/quicktakes/2017/03/03/study-first-year-orientation-and-retention

Friedlander, L. J., Reid, G. J., Shupak, N., \& Cribbie, R. (2007). Social support, self-esteem, and stress as predictors of adjustment to university among first-year undergraduates. Journal of College Student Development, 48(3), 259-274. https://doi.org/10.1353/csd.2007.0024

Gong, X., \& Huybers, T. (2015). What attracts Chinese students to Aussie universities? The Conversation. Retrieved from http://theconversation.com/what-attracts-chinesestudents-to-aussie-universities-46748

Hamaideh, S. H. (2011) Stressors and reactions to stressors among university students. International Journal of Social Psychiatry, 57(1), 69-80. https://doi.org/10.1177/0020764010348442

Heaton, J. (1998). Secondary analysis of qualitative data. Social Research Update, Autumn(22). Retrieved from http://sru.soc.surrey.ac.uk/SRU22.html

Hillman, K. (2005). The first year experience: The transition from secondary school to university and TAFE in Australia. Longitudinal Surveys of Australian Youth (LSAY) Research Report, 44(40). http://research.acer.edu.au/lsay research/44

Johnson, L., Adams Becker, S., Cummins, M., Estrada, V., Freeman, A., \& Hall, C. (2016). NMC horizon report: 2016 bigher education edition. Austin, Texas: The New Media Consortium. Retrieved from https://www.sconul.ac.uk/sites/default/files/documents/2016-nmc-horizon-report-he-EN-1.pdf

Kantanis, T. (2000). The role of social transition in students' adjustment to the first-year of university. Journal of Institutional Research, 9(1), 100-110. Retrieved from http://www.aair.org.au/app/webroot/media/pdf/JIR/Journal $\% 20$ of $\% 20$ Institutional $\% 20$ Research $\% 20$ in \%20Australasia $\% 20$ and $\% 20$ JR/Volume $\% 209 \% \% 20$ No. $\% 201 \% 20$ May $\% 202000 /$ Kantanis.pdf

Kift, S. (2014). Student success: Why first year at uni is a make-or-break experience. The Conversation. Retrieved from http:/ / theconversation.com/student-success-why-first-year-at-uni-is-a-make-or-break-experience$\underline{21465}$

Konovalov, D. E., Sealey, R., \& Munns, S. (2017). A cohesive student support model provides integrated support to at risk students at a regional Australian university. In Proceedings of the Students Transitions Achievement Retention and Success Conference (pp. 1-10). Retrieved from https://researchonline.jcu.edu.au/49557/

Larmar, S., \& Ingamells, A. (2010). Enhancing the first-year university experience: Linking university orientation and engagement strategies to student connectivity and capability. Research in Comparative and International Education, 5(2), 210-223. https://doi.org/10.2304/rcie.2010.5.2.210

Lizzio, A. (2006). Designing an orientation and transition strategy for commencing students: Applying the five senses model. Griffith University: First Year Experience Project. http:/ fyhe.com.au/wpcontent/uploads/2012/10/Lizzio-TheFivesensesofStudentSuccessSelfAssessmentFrameworkforplanningandreviewofOT doc.pdf

Maani, S. A. (2006). Parental income and choice of participation in university, polytechnic or employment at age 18: A longitudinal study. In J. Creedy, \& G. Kalb (Eds.) Dynamics of inequality and poverty (pp. 217-248). Bingley: Emerald Group Publishing. https://doi.org/10.1016/S1049-2585(06)13008-2

Maaz, K., \& Watermann, R. (2007). Reproduction or mobility? The effects of family process variables on intentions to enter higher education. Zeitschrift für Soziologie der Erziehung und Sozialisation, 27(3), 285-303. 
Macaskill, A., (2013) The mental health of university students in the United Kingdom. British Journal of Guidance \& Counselling, 41(4), 426-441. https://doi.org/10.1080/03069885.2012.743110

Maguire, M., \& Delahunt, B. (2017). Doing a thematic analysis: A practical, step-by-step guide for learning and teaching scholars. AIS HE-J: The All Ireland Journal of Teaching and Learning in Higher Education, 9(3), 3351-

33514. Retrieved from http://ojs.aishe.org/aishe/index.php/aishe-j/article/viewFile/335/553

Payne, G., \& Payne, J. (2004). Secondary analysis. In Key concepts in social research. SAGE Online Publication. https://doi.org/10.4135/9781849209397.n45

Penman, J. (2005). 'Preparing for Sciences' workshop: A new initiative for Whyalla nursing students. In Annual International HERDS A Conference on Higher Education in a Changing World (pp. 381-388). Milperra, NSW: Higher Education Research and Development Society of Australasia (HERDSA) Inc.. Retrieved from http://conference.herdsa.org.au/2005/pdf/refereed/paper 049.pdf

Pittman, L. D., \& Richmond, A. (2008). University belonging, friendship quality, and psychological adjustment during the transition to college. Journal of Experimental Education, 76(4), 343-362. https://doi.org/10.3200/JEXE.76.4.343-362

Prasad, J. J., Showler, M. B., Ryan, A. M., Schmitt, N., \& Nye, C. D. (2017). When belief precedes being: How attitudes and motivation before matriculation lead to fit and academic performance. Journal of Vocational Behavior, 100, 27-42. https://doi.org/10.1016/i.jvb.2017.02.003

Reblin, M. A., \& Uchino, B. N. (2008). Social and emotional support and its implication for health. Current Opinion in Psychiatry, 21(2), 201-205. https://doi.org/10.1097/YCO.0b013e3282f3ad89

Scutter, S., Palmer, E., Luzeckyj, A., Burke da Silva, A., \& Brinkworth, R. (2011). What do commencing undergraduate students expect from first year university? International Journal of the First Year in Higher Education, 2(1), 8-20. https://doi.org/10.5204/intjfyhe.v2i1.54

Stallman, H. M. (2010). Psychological distress in university students: A comparison with general population data. Australian Psychologist, 45(4), 249-257. https://doi.org/10.1080/00050067.2010.482109

Stebleton, M. J., Soria, K. M., \& Huesman, R. L. (2014). First-generation students' sense of belonging, mental health, and use of counseling services at public research universities. Journal of College Counseling, 17(1), 617. https://doi.org/10.1002/i.2161-1882.2014.00044.x

Strawiński, P. (2011). Educational aspirations. Working papers No.10/2011(50). Warsaw: University of Warsaw. Retrieved from http://www.wne.uw.edu.pl/files/1413/9628/6202/WNE WP50 2011.pdf

Szabo, V., \& Strang, V. R. (1997). Secondary analysis of qualitative data. Advances in Nursing Science, 20(2), 66-74. https://doi.org/10.1097/00012272-199712000-00008

Thalluri, J. (2016). Bridging the gap to first-year health science: Early engagement enhances student satisfaction and success. Student Success, 7(1), 37-48. https://doi.org/10.5204/ssj.v7i1.305

Thorne, S. (1990). Secondary analysis in qualitative research: Issues and implications. In J. M. Morse

(Ed.) Critical issues in qualitative research methods. London: Sage.

UNICEF (n.d.). Definition of psychosocial supports. Retrieved from https://www.unicef.org/tokyo/jp/Definition of psychosocial supports.pdf

University Business (2017). Student anxiety on the rise. University Business: The Business of Higher Education. Retrieved from https://universitybusiness.co.uk/Article/student-anxiety-on-the-rise/2017

Vaismoradi, M., Turunen, H., \& Bondas, T. (2013). Content analysis and thematic analysis: Implications for conducting a qualitative descriptive study. Nursing and Health Sciences, 15(3), 398-405.

https://doi.org/10.1111/nhs.12048

Wilcox, P., Winn, S., \& Fyvie-Gauld, M. (2005). It was nothing to do with the university, it was just the people: The role of social support in the first-year experience of higher education. Studies in Higher Education, 30(6), 707-722. https://doi.org/10.1080/03075070500340036

Wilson, K., \& Lizzio, A. (2008). A 'just in time intervention' to support the academic efficacy of at-risk firstyear students. In 11th Pacific Rim First Year in Higher Education Conference, Hobart, Australia, Refereed Paper. Retrieved from http://fyhe.com.au/past papers/papers08/FYHE2008/content/pdfs/6b.pdf 
Wilks, J., \& Wilson, K. (2012). Going on to uni? Access and participation in university for students from backgrounds of disadvantage. Journal of Higher Education Policy \& Management, 34(1), 79-90. https://doi.org/10.1080/1360080X.2012.642335

Wong, J. G. W. S., Cheung, E. P. T., Chan, K. K. C., Ma, K. K. M., \& Tang, S. W. (2006). Web-based survey of depression, anxiety and stress in first-year tertiary education students in Hong Kong. Australian \& New Zealand Psychiatry, 40(9), 777-782. https://doi.org/10.1111/j.1440-1614.2006.01883.x

\section{BIOGRAPHIES}

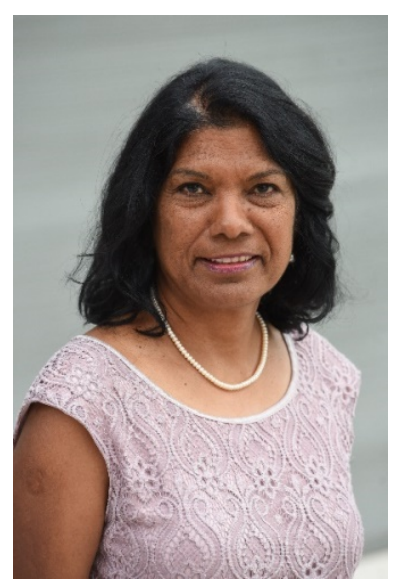

Dr Jyothi Thalluri is a Senior Lecturer and has extensive experience in 'service teaching' Human Anatomy/Physiology, Neurosciences and Pathology courses to various allied health science programs in the Division of Health Sciences, UniSA. Jyothi has a keen interest in the learning and teaching dynamics associated with student academic, social and cultural diversity. She has a firm belief that students need various learning options and appropriate support, particularly when transitioning into university study. She has demonstrated an ongoing commitment to the implementation of many innovative initiatives, to engage, support and provide flexible and student-centred learning options. She has used these to enhance outcomes within a diverse range of student cohorts. Jyothi has won many teaching awards and has published several papers in peer-reviewed international teaching and learning journals.

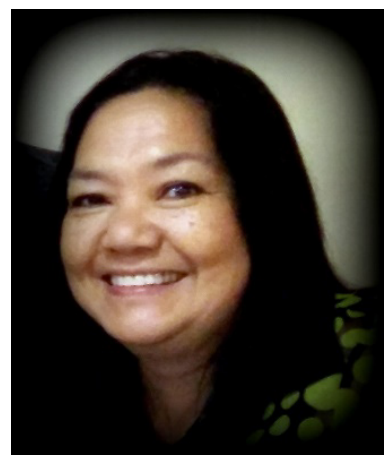

Dr Joy Penman is currently a Senior Lecturer in Nursing and Midwifery at the Monash University. She has over thirty years teaching experience locally and abroad and many years nursing experience in various healthcare facilities. Joy has extensive experience in research and community engagement. In recognition of her contribution to these areas, she has been a recipient of multiple teaching, research and community service awards. Joy has been involved in various research projects. She is well published in peer-reviewed journals and books and has presented her work at national and international conferences. 